\title{
Afirmar a vida no encontro entre o cinema e uma formação de professoras
}

\section{Affirming life in the meeting between cinema and teacher training}

\section{Afirmar la vida en el encuentro entre cine y formación docente}

\author{
Steferson Zanoni Roseiro ${ }^{1}$ \\ Suzany Goulart Lourenço ${ }^{2}$ \\ Janete Magalhães Carvalho ${ }^{3}$
}

DOI: http://dx.doi.org/10.20435/serie-estudos.v26i58.1574

\begin{abstract}
Resumo: Objetiva problematizar os modos de pensar e praticar os currículos no cotidiano escolar em direção ao fortalecimento do apego à vida na escola a partir de discussões e ideias decorrentes de uma pesquisa-formação no contato com dois curtas-metragens. Metodologicamente, foram criadas redes de conversações com professoras de uma Rede Municipal de Ensino, para tensionar o limite do corpo-indivíduo em direção à produção de coletivos verdadeiramente implicados com os pensamentos curriculares, partindo de dois curtas-metragens como elementos disparadores para as conversações: L3.o (2014) e Piirongin Piiloissa (2011). Por meio das imagens-cinema apresentadas, notou-se uma movimentação do pensamento das professoras, ao atualizarem enunciações acerca da vida escolar e de seus limites, destacando as rasuras produzidas pela emoção criadora que expandem o apego à vida. Por fim, conclui que o apego à vida é necessário para liberar a vida e permitir a passagem da pulsão vital que dá acesso à potência de criação e, assim, das problematizações e criações docentes.
\end{abstract}

Palavras-chave: currículo; apego à vida; imagem-cinema.

Abstract: It aims to problematize the ways of thinking and practicing the curricula in everyday school life towards strengthening the attachment to life in school from discussions and ideas arising from a research-training in contact with two short films. Methodologically, networks of conversation were created with teachers of a Municipal Education Network, to stretch the limit of the individual-body towards the production of collectives truly involved with curricular thoughts, starting from two short films as triggering elements for the conversations: L3.o (2014) and Piirongin

\footnotetext{
${ }^{1}$ Prefeitura Municipal de Cariacica, Cariacica, Espírito Santo, Brasil.

2 Universidade Vila Velha (UVV), Vila Velha, Espírito Santo, Brasil.

${ }^{3}$ Universidade Federal do Espírito Santo (UFES), Vitória, Espírito Santo, Brasil.
} 
Piiloissa (2011). Through the cinema-images presented, we noticed a movement in the teachers' thoughts, as they updated statements about school life and its limits, highlighting the erasures produced by the creative emotion that expand the attachment to life. At last, it concludes that the attachment to life is necessary to release life and allow the passage of the vital drive that gives access to the power of creation and, thus, to the problematization and creations of teachers.

Keywords: curriculum; attachment to life; cinema-image.

Resumen: Tiene como objetivo problematizar los modos de pensar y practicar los currículos en el cotidiano escolar hacia el fortalecimiento del apego a la vida en la escuela a partir de discusiones e ideas surgidas de una investigación-formación en contacto con dos cortometrajes. Metodológicamente, se crearon redes de conversación con docentes de una Red Municipal de Educación, para estirar el límite del individuo-cuerpo hacia la producción de colectivos verdaderamente involucrados con los pensamientos curriculares, a partir de dos cortometrajes como elementos desencadenantes de las conversaciones: L3.o (2014) y Piirongin Piiloissa (2011). A través de las cine-imágenes presentadas, notamos un movimiento en el pensamiento de los docentes, en la medida en que actualizaban los enunciados sobre la vida escolar y sus límites, destacando las borraduras producidas por la emoción creadora que expanden el apego a la vida. Finalmente, concluye que el apego a la vida es necesario para liberar la vida y permitir el paso de la pulsión vital que da acceso al poder de creación y, por tanto, a la problematización y creaciones de los docentes.

Palabras clave: currículo; apego a la vida; cine-imágenes.

\section{INTRODUÇÃO}

É possível afirmar a vida na escola? Nesses tempos de pandemia de covid-19, quando a escola é um potencial risco biológico, quais forças nela afirmam a vida? Muito aquém e além da pandemia e de todo vírus-morte, a escola pode ser uma zona de contágio e propagação de afetos, sensibilizando os corpos e produzindo um apego à vida? Podem as práticas curriculares cotidianas instaurar nas escolas forças vitalistas? Quais forças podemos evocar para isso? Quais forças podem tensionar os currículos em direção a uma vida mais alegre?

Em março de 2020, as escolas brasileiras iniciavam o processo de suspensão das aulas por causa do avanço da pandemia de covid-19. Tão logo iniciou as estratégias de isolamento social, a escola pública viu-se imediatamente limitada, dadas as suas condições de trabalho, dados os recursos profissionais e estudantis, dadas as próprias conceitualizações sobre aula e o papel da escola. É, afinal, possível fazer escola em pleno período de pandemia? É possível afirmar a escola na pandemia e para além dela?

O ano de 2020 marcou fortemente os limites da educação escolar pública.

Por um lado, fomos tomados de assalto pela invasão das tecnologias da co- 
municação. Professoras e professores que, antes, nem sequer podiam fazer seus planejamentos em escolas, por ausência de dispositivos tecnológicos, viram-se de repente munidos de e-mails institucionais, de formações para usar essa ou aquela ferramenta digital, de cobranças de tempos muito além de suas cargas horárias semanais. Em 2020, os limites entre o público e o privado foram borrados pela captura das telas, pela extensão da realidade por meio do touchscreen, dos abraços virtuais e das socializações remotas. E isso apenas sob a ótica das professoras, desconsiderando ainda todo o contexto de dificuldade de acesso a tais dispositivos remotos de comunicação, bem como o acompanhamento necessário aos alunos por parte de responsáveis.

A escola pública nascida em meio à pandemia parece uma planície de verdume imenso. E tal é a imensidão que ali nada vive, tudo se desola.

Além do mais, evidentemente, apostamos que a escola não morrerá em sua versão pandêmica. A escola em tempos de pandemia não pode e não será a última versão dessa instituição, apesar do que aparentam os tempos. Há muito mais força na escola do que as condições de isolamento nos permitem enxergar.

Quais, afinal, são as implicações da escola para a vida? O que quer uma escola?

Apostando em uma perspectiva conhecida como filosofia da diferença, proposta em grande parte por Gilles Deleuze e Félix Guattari, pensamos numa escola em contínua afirmação da vida (DELEUZE, 2018), isto é, uma escola que produz, em suas práticas, menos a restrição dos sentidos e mais uma contínua ampliação dos possíveis. A afirmação da vida passa, aos modos de Deleuze, pela borra das fronteiras entre o real imediato e suas virtualidades, entre o que é impensável e a imanência.

Eis nossa proposta inicial como professoras e professores na educação pública: pensar a escola e, por conseguinte, as práticas curriculares requer que tomemos todas as ações ocorridas dentro do contexto escolar como práticas que ampliem as nossas potências de agir em direção a uma criação de uma comunalidade entre os corpos curriculares (CARVALHO, 2009).

Pensando, desse modo, as discussões sobre a afirmação da escola e a multiplicação de uma força vitalista mediante as práticas curriculares, colocamo-nos em pesquisa-formação com professoras da Rede Municipal de Ensino. Entre maio e setembro de 2021, reunimo-nos virtualmente com 14 professoras, para discutir e problematizar o lugar dos currículos e da arte na escola ${ }^{4}$. Metodologicamente,

${ }_{4}$ Inicialmente, a pesquisa foi pensada para 75 professoras, tendo passado por uma grande 
foram criadas redes de conversações (CARVALHO, 2009) com as professoras, para tensionar o limite do corpo-indivíduo em direção à produção de coletivos verdadeiramente implicados com os pensamentos curriculares, partindo de dois curtas-metragens como elementos disparadores para as conversações: L3.O $(2014)^{5}$ e Piirongin Piiloissa $(2011)^{6}$.

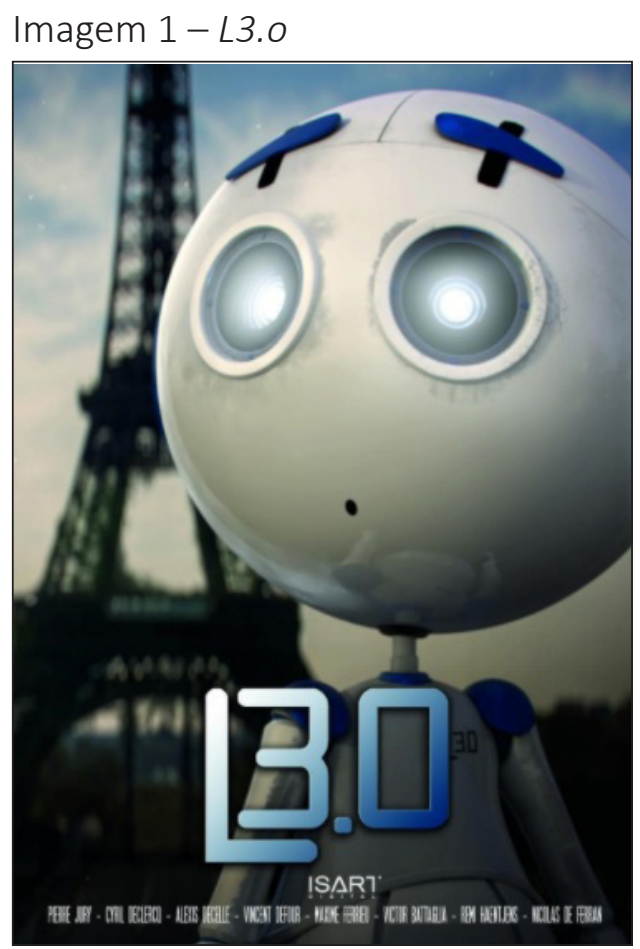

Fonte: https://www.imdb.com/title/tt4114454/

mudança, visto que, às vésperas do início da formação, o município em questão - assim como todos os outros municípios da região metropolitana do estado - foi fortemente pressionado pelo Ministério Público para adiantar o retorno das aulas presenciais no modelo híbrido. Com o retorno de trabalho presencial, as professoras viram-se em conflitos de horário para participar das formações, resultando, com isso, em uma diminuição brusca do número de inscritos. Contudo, ainda nesse contexto de retorno de trabalho presencial e necessidade de flexibilização de horário por parte das professoras e dos grupos formadores, a formação foi mantida com um total de 42 professoras inscritas e divididas em três grupos. Para o texto aqui apresentado, selecionamos apenas parte do material produzido com um dos grupos de formação, contendo um total de 14 professoras.

${ }^{5}$ Disponível em: https://www.youtube.com/watch?v=dQT3wD9gweE

${ }^{6}$ Disponível em: https://www.youtube.com/watch?v=HwUZ2kH1id0 


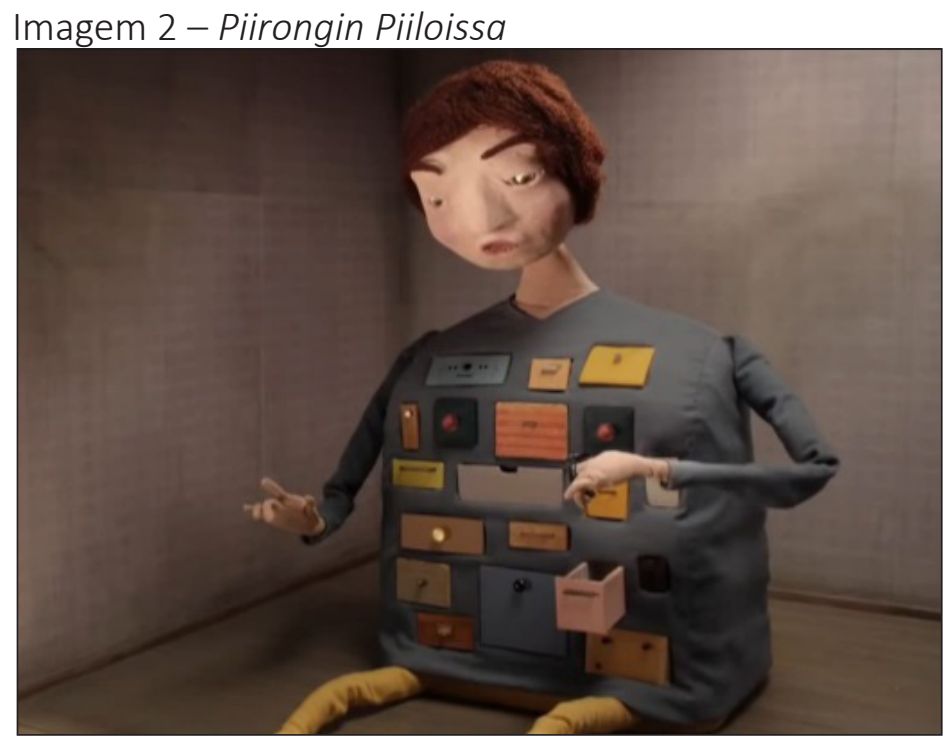

Fonte: https://www.imdb.com/title/tt3080164/

Ao longo do texto, trechos das conversas produzidas em conexões com os curtas aparecerão em itálico e entre aspas (quando curtos) ou alinhados à esquerda, itálico e com espaçamento simples (quando longos), não apresentando nenhum modo de identificação, visto que, para nós, toda fala e todo corpo remetem a um agenciamento coletivo de enunciação (DELEUZE; GUATTARI, 1995, p. 64-5), isto é, partimos do princípio de que cada corpo "[...] é envolvido num tal agenciamento, reproduz o enunciado quando acredita falar em seu nome ou antes fala em seu nome quando produz o enunciado".

Objetivamos, assim, problematizar os modos de pensar e praticar os currículos no cotidiano escolar em direção ao fortalecimento do apego à vida na escola a partir de discussões e ideias decorrentes de uma pesquisa-formação no contato com os dois curtas-metragens. Desse modo, tencionamos que, por meio dos usos de imagens-cinema, professoras ampliassem os processos de problematizações para outros novos modos de aprender, pois as narrativas cinematográficas possibilitam desconstruir e deslocar os conhecimentos clichês petrificados nos cotidianos escolares, assim como movimentam o pensamento em busca de abertura para outros jeitos e outras composições de ser e estar escola.

Assim, com o objetivo de problematizar quais as potências da escola diante do quadro nefasto que vivenciamos, começamos simplesmente por indagar: quais, 
afinal, são as possibilidades curriculares em uma escola? Como o encontro com o cinema (curtas-metragens) fomenta a problematização do plano de imanência da escola percebido, vivido, afetado pelas professoras nos currículos escolares? É possível as imagens-cinema expandirem o apego à vida de professores e professoras em relação aos processos aprendentes que se atualizam nas escolas?

\section{A FORÇA DAS IMAGENS-CINEMA NA EXPANSÃO DO APEGO À VIDA}

Ao falar sobre cinema, partindo da leitura de Bergson (2006) sobre o movimento, Deleuze $(1985,2013)$ distingue três tipos de imagens compondo a imagem-movimento: a imagem-percepção, a imagem-ação e a imagem-afecção. Para Bergson (2006), as afeç̧ões intercalam-se entre os estímulos que são recebidos (imagem-percepção) e os movimentos executados (imagem-ação), ocupando um "entre" como elemento produtor e produto de afecções que podem movimentar o pensamento e, desse modo, a aprendizagem inventiva (CARVALHO, 2014).

Deleuze, então, com base na ideia bergsoniana de que tudo é imagem, convoca-nos a pensar em imagens-cinema que se constituem em esquemas sensório-motores, ou seja, evidenciam narrativas baseadas em ação-reação. Tratase, assim, de um sistema composto por uma imagem-percepção (movimento de corpos como substantivos) e uma imagem-ação (movimento como verbo) centralizadas num personagem, imagens-movimento. Imagens que estabelecem um mundo estático, no qual há uma única perspectiva: enquadramentos e montagens de imagens que estagnam a vida.

Além dessas, existem ainda imagens que rompem com a linearidade temporal das narrativas, imagens-tempo que deslocam nossa percepção por afecções indiscerníveis, ultrapassando os esquemas sensório-motores pelos quais se afirmam as imagens-ação, e imagens que se manifestam por uma pluralidade de centros, multiplicidades que se desenrolam na simultaneidade entre passado, presente e futuro. Assim,

[...] todas as imagens reagem umas sobre as outras, sobre todas as suas faces e em todas as suas partes. É o regime da variação universal, que ultrapassa os limites humanos do esquema sensório-motor, rumo a um mundo não humano, onde movimento é igual a matéria, ou então rumo a um mundo sobre-humano, que atesta um espírito novo. É aí que a imagem-movimento atinge o sublime. (DELEUZE, 2013, p. 54). 
Nessa perspectiva, não é mais o esquema sensório-motor que é convocado, e sim a vidência, pois o acontecimento passa a ser uma situação ótica e sonora pura, investida pelos sentidos, uma descrição físico-geométrica/inorgânica que se faz por meio de uma imagem atual, mas que, em vez de se prolongar em movimento, conjuga-se com imagens-virtuais, formando um circuito independente do esquema sensório-motor.

As imagens-tempo invertem a relação de subordinação do tempo ao movimento, produzindo novas relações entre os elementos óticos e sonoros. O tempo passado não se produz após o presente sucessivamente, mas duram ao mesmo tempo. Produz-se uma cisão que Deleuze chama de imagem-cristal, pela qual vislumbramos o jorro do tempo não cronológico. Uma imagem que dura, ou seja, conserva-se no espaço que ocupa.

É por isso que esse contínuo de variação universal é uma continuidade de duração numa profundidade de tempo, e não de espaço, só possível num pensamento que transgride os esquemas sensório-motores, numa existência eminentemente trágica, só exprimível por meio da arte, do delírio, do sonho... Possível pela cintilação das imagens-cristal que compõem as imagens-tempo.

As imagens-cristal instauram-se por uma espécie de duplo entre uma imagem atual e "sua" imagem virtual, como quando as professoras veem, no contexto do olhar para a escola, para a cidade, para a vida, a possibilidade de superação da brutalidade instalada nos corpos embrutecidos por gestos de afeto e compaixão.

A partir de imagens-cristal e seus jogos de duplos e espelhos nas imagens-cinema, podemos pensar em uma das características mais contundentes das imagens: a imagem dentro da imagem ou a imagem no espelho. Neste caso, a imagem é uma máquina de pensar, de pensar possibilidades de inverter o caminho habitual da vida, dos processos de aprender-ensinar no cotidiano escolar, buscando renovar a existência e realizar, pelo pensamento problematizado, novos ângulos e percepções para o mundo; enfim, produzir imagens novas para o mundo e um mundo de novas imagens (CARVALHO, 2015).

É apostando na força de imagens-cinema que desdobram imagens-cristal que ousamos fazer entrar em relação os curtas-metragens supracitados e as professoras que compuseram o percurso formativo, pois são imagens que, ao deslocarem os esquemas sensório-motores, podem potencializar o apego à vida nos cotidianos escolares. Se nos disserem "Você será organizado, você será um 
organismo, articulará seu corpo - senão você será um depravado. Você será significante e significado, intérprete e interpretado - senão será desviante" (DELEUZE; GUATTARI, 1996, p. 22), agarrar-nos-emos aos desvios que fazem bifurcar o pensamento e contribuem na efetuação de outros mundos possíveis.

Conforme ressalta David Lapoujade (2017), também com base em Henri Bergson, há uma tendência de atenção à vida que envolve um certo tipo de reconhecimento necessário a todo corpo-vivo. Viver implica em atentar-se ao que se passa nos arredores. Desse modo, a atenção à vida seria primeiramente determinada pelas montagens sensório-motoras, isto é, pela nossa capacidade de sentir/perceber a vida ao redor. Porém, ante a discussão bergsoniana, tal conceito implicaria uma necessária adaptação do corpo-vivente ao que é decidido e existe socialmente. Para Lapoujade (2017, p. 104), esse movimento de adaptação do corpo-vivente à vida exterior ocorreria porque nossa inteligência "[...] apegou-se a formas e seres que ela primeiro recortou, e depois fixou na continuidade movente das coisas". Logo, trata-se de uma tendência de resposta às exigências sociais.

Por outro lado, mas atuando paralelamente, o apego à vida trata de uma tendência que se pode desenrolar por diferentes linhas: pelo "todo da obrigação", no qual o apego à vida ocorre de forma indireta; pelo apego aos outros (família, instituições, pátria), constituindo-se como um modo de a sociedade se fazer obedecer; pela "função fabuladora", pela qual deliramos no mundo mediante nossas crenças que aumentam nosso sentimento de confiança com um coletivo e produzimos espécies de delírios no mundo para viver; por fim, pela "emoção criadora", que impulsiona os movimentos, e não as formas, inserindo-se no intervalo inteligência-sociedade (LAPOUJADE, 2017; DELEUZE, 2004).

Desse modo, com o apego à vida que se produz pela emoção criadora, abrimo-nos a uma pluralidade de mundos, rompemos com o círculo ação-reação imposto pelas imagens-movimento que nos circundam e circunscrevem e compomos, pelas imagens-cristal, novos conceitos e novas imagens do pensamento. Tais imagens não dogmáticas, mas cristalinas, que afloram corpos desejantes para se potencializarem ainda mais, no caso da pesquisa indicada nesta escrita, pela força das redes de conversações na composição de corpos coletivos.

Se o mundo é constituído por imagens, convivemos com múltiplas imagens que forçam o movimento de atualização, fazendo a duração vibrar ora para 
tendências de ação-reação por meio da atenção à vida, ora para tendências que nos abrem à potência da vida, ampliando a emoção criadora, indo de encontro ao que a maquinaria capitalista tem a nos oferecer: coletivismos abstratos, individualismo, propriedades, interesses vazios. Esta última tendência, do apego à vida, não faz desaparecer os esquemas sensório-motores, mas se aproveita deles para atualizar processos de subjetivação que escapam do egoísmo individual e da pressão social (LOURENÇO, 2019).

Assim foram nossas redes de conversações com as professoras. Entramos em relação com imagens-cinema no intuito de sacudir os clichês que habitam os cotidianos escolares, quebrá-los pelo movimento do pensamento que faz subir à superfície o apego à vida, contrapondo verdades fixadas em imagens dogmáticas, buscando novos mundos possíveis e/ou novas possibilidades de realização/ invenção nos modos de pensar e praticar os currículos escolares.

\section{CURRÍCULOS ENTRE A ATENÇÃO À VIDA E O APEGO À VIDA}

O curta-metragem começa, e o silêncio é categórico - microfones desligados.

$\mathrm{Na}$ tela, um som animado parece sair de uma vitrola. O cenário inicial parece uma Paris perdida no tempo, com uma casa nitidamente vivida, com típicas bagunças de criança espalhadas pelo chão, prontamente decorada para um natal vindouro.

Até mesmo o ar da cena nos convida a entrar em um clima de placidez.

E, estreando a cena, um robô transita entre televisão, uma clássica partida de Monopoly e um ursinho de pelúcia. Nas telas, as professoras se aquiescem diante de sua presença. Como desdobra, uma professora diz: "Ali eu vi que ele queria encontrar alguém para se divertir". Deveras, o robô não tarda a efetuar sua busca indicada. Sentado à escrivaninha, escreve cartas e dobra-as em formato de aviãozinho. O cenário muda, e ele já não mais está dentro de casa. Sua busca - pelo outro - exige que se expanda no ambiente externo. Vale-se dos aviõezinhos, lança-os do alto de um morro em direção à cidade pacata logo abaixo. No interior das cartas, uma única mensagem: "Olá, meu nome é Leo. Por favor, venha brincar comigo".

A frase da professora ecoa conosco: "Ali eu vi que ele queria encontrar alguém para se divertir". Ora, quando pensamos na força da escola em proporcionar vida, não seria justamente essa uma questão a ser pensada com seriedade? Não pode a escola compor também relações de amizades? Ao querer afirmar a vida, não seria também preciso que a escola compusesse, entre os corpos que por ela 
transitam, afetividades comuns, isto é, criasse com eles pontos de encontro entre conhecimentos e o desejo de compor juntamente, de aliar-se a outros? "Ali eu vi que ele queria encontrar alguém para se divertir, mas não teve muito sucesso". O cenário do curta, entretanto, muda radicalmente.

Robô e borboleta tomam a cena após um corte. Borboleta em primeiro plano, no fundo, apenas os olhos luminosos do pequeno robô. Olhos a observá-la. E observam. Tudo parece muito bem posicionado e perfeitamente observável. Os limites do cognoscível são as barreiras de vidro que prendem a borboleta desesperada a bater suas asas. "Eu fiquei lembrando daqueles momentos que a gente quer fazer um trabalho fantástico, e aí a gente pega essa porcaria [mostra o celular], tira uma foto e parece que se resume só naquela foto daquele momento".

Observando, o pequeno robô faz, ao som de uma sonoplastia encantadora, o resultado final de seu experimento: uma dobradura da borboleta em observação. Dobradura feita à perfeição representativa! Faz a dobradura e observa atentamente, dentro do pote de vidro, os últimos bater de asas da borboleta-experimento.

Fora de serventia, despeja os restos da vida copiada dentro da lixeira e segue.

Resta-lhe apenas a dobradura perfeita de uma borboleta, que, logo mais, é mostrada ao lado de uma dobradura-aranha, dobradura-vespa, dobradura-galo, dobradura-cão, dobradura-humano...

Imagem 3 - Restos de uma vida

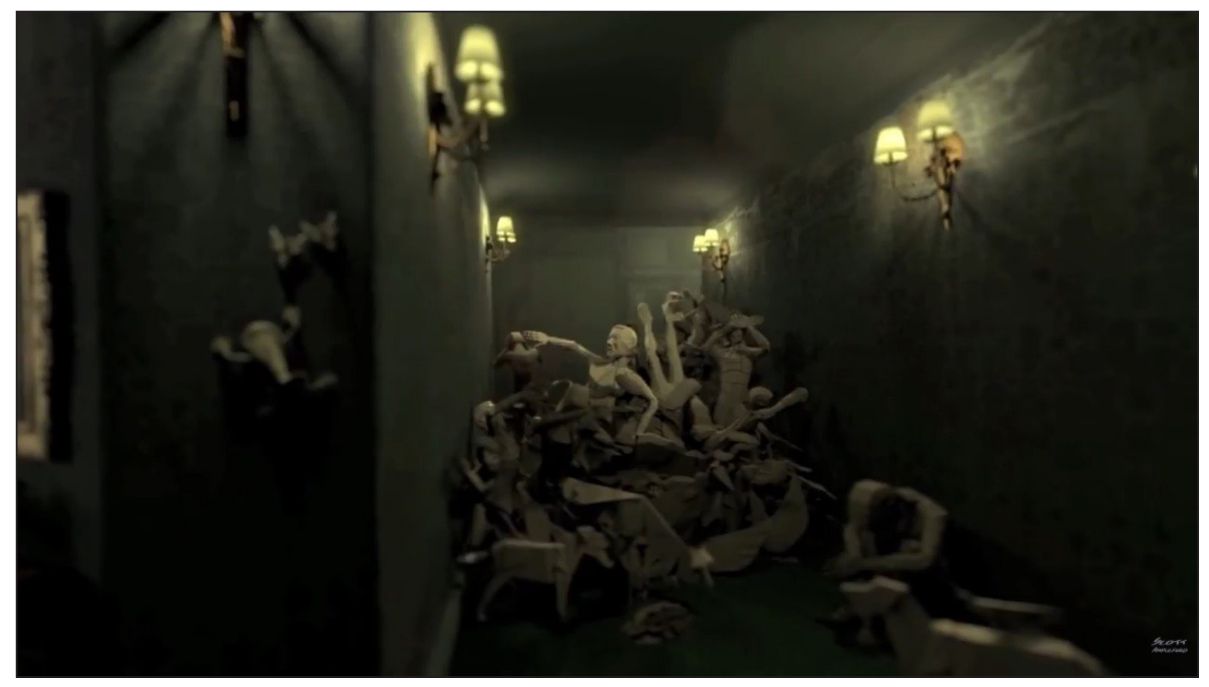

Fonte: L3.o (2014). 
Vida enclausurada, vida replicada, vida descartada.

Ora, quando tomamos os currículos escolares na perspectiva de uma realidade replicada, estanque e a ser reproduzida, não estaríamos, aos modos desse pequeno robô, capturando a vida e dando a ela a eternidade do papel em sua morte? Quando os currículos se resumem a conhecer a vida em morte, isto é, a reconhecer a vida unicamente como algo reproduzível, parece nada mais restar à própria vida.

Assim, o conhecimento dá à vida leis que a separaram do que ela pode, que a poupam de agir e a proíbem de agir, mantendo-a no quadro estreito das reações cientificamente observáveis: mais ou menos como o animal num jardim zoológico. (DELEUZE, 2018, p. 129).

Mas os currículos se resumem a esse enclausuramento? A vida pode ser capturada e replicada em um pedaço de papel? São os currículos um processo de aprisionar a vida e transformá-la em dobraduras para circular infinitamente por entre mãos desconhecidas, mãos de precisão quase cirúrgicas que apenas reviram os gomos do papel para ver como repetir as dobras? Ou estaria a vida curricularizada sempre dentro dos limites do papel?

Como pontuou uma professora, seria o currículo um processo de coisificação?

Eles [os curtas] mexem muito com a gente mesmo porque ele [L3.o] quer só coisificar, ele manda as cartas, convida, né, mas ele quer só aquele momentinho que ele produz, coisifica e vai engessando... Ele vai abandonando porque não serve mais, perdeu a graça, né? É muito forte! Eu achei muito forte.

Para responder a tal questão, primeiramente precisamos compreender o que seria limitar a vida às dobras de um papel. O conceito de atenção à vida ajuda-nos a falar justamente dessa força motriz, de um certo modo de conhecer a vida que a mortifica. Se a atenção à vida é a tendência que nos intima às pressões sociais, poderíamos nós, professores e professoras, assim como o personagem-robô, enclausurar nossos alunos para moldá-los mediante uma ideia de adaptação necessária do corpo-vivente ao que a sociedade nos impõe?

No curta-metragem, a atenção à vida poderia ser aliada ao próprio movimento dos dedos do pequeno robô que se preocupa apenas com a fidedignidade de seus arredores, em reproduzir com exatidão a forma para estancar seu movimento, mesmo tentando reinserir o corpo-dobradura de volta no movimento da própria vida. 
"Essa amizade a gente não quer, não!", diz uma professora ao se referir à carta escrita por L3.o. Diz e ri como quem escancara as forças indizíveis de uma vida demasiadamente sufocante.

E, apesar do peso lascivo do curta, o que surge na conversa com as professoras é de outra realidade: evoca o período de trabalho durante a pandemia e, no limite, almeja um tempo para além dela.

Até misterioso o filme, a gente fica meio assustado no final, né? E como que a tecnologia nos ajuda. Ali eu vi que ele queria encontrar alguém para se divertir, mas não teve muito sucesso... eu vejo que a gente tem que saber utilizar a tecnologia nos nossos trabalhos, tem que saber como atingir esse aluno, tem que ter um olhar sensivel, saber produzir, colocar ali de forma que vá atender essa família, vá chegar até essa criança porque nós sabemos que nem todos têm acesso [ao ensino remoto], então, buscar de um jeito ou de outro para que eles possam ter as informações necessárias.

Eu estava lembrando, eu acabei sentindo porque há dois anos, a gente tinha todo um julgamento das redes na vida das crianças e dos adolescentes, de crianças que ficavam muito tempo na internet em casa ligado, chamava os pais, fazia palestra pra cá, palestra pra lá. E eu lembro que eu tinha um aluno, ele faltava muito, e numa conversa com a família, a mãe mostrou 0 YouTube do menino, ele era um youtuber na escola e tinha 5 mil seguidores há dois anos. Então, era uma criança que aquele monte de papel que a gente produzia na escola não dialogava com o que ele produzia fora da escola. $E$ isso é muito recorrente nas escolas, a maneira e até a linguagem que essas crianças falam: "olá, galerinha!", a gente ficava demonizando, falando muito mal de como usava e como agora na escola a gente usa tanto esse recurso e a gente tem que tentar valorizar isso, de como usar essa tecnologia valorizando, porque eles usam muito mesmo.

Ora, o que nos dizem essas falas?

Em primeiro lugar, elas evidenciam que uma questão peculiar no próprio conceito de atenção à vida, ainda que a atenção à vida seja definida por sua relação com o arco sensório-motor e ainda que ela faça composição com a lógica de ajustamento da vida às condições imediatas, também nos empurra para o limite do dizível e visível. Se nos contentássemos apenas em viver, os automatismos já seriam suficientes. Contudo, no limite do dizível e visível, sofremos perturbações em nossos esquemas sensório-motores, ou, como Lourenço (2019) propõe, diante das situações mesmas de ajustamento da vida às exigências sociais imediatas, o corpo pode simplesmente disso tudo rir e expor, assim, as fraquezas da força condutora da vida. 
Embora o curta seja trágico, ele é atravessado por uma professora que grita-e-ri "Essa amizade a gente quer, não!", fazendo, então, proliferarem outras ideias, entrando em conversa com a pandemia de covid-19 para evocar uma memória de tempos em que as tecnologias da comunicação eram, em grande parte, as arqui-inimigas da educação pública escolarizada. "Ao rirmos desses automatismos, podemos convocar a atenção à vida a um deslocamento no pensamento" (LOURENÇO, 2019, p. 39). Logo, por dentro dos automatismos que nos espreitam, vemos o apego à vida, que é forçado pela própria vida, insurgir pelo desejo de composições que não nos enclausurem.

Concomitantemente, somos provocados, também, pela discussão sobre as tecnologias apresentadas pelas professoras. Conseguimos aproximar-nos das telas e das tecnologias de comunicação sem incorrer o risco de nos robotizarmos? É possível pensar as práticas curriculares em tempos de pandemia que ultrapassem a robotização da vida? Que se aproximem dos alunos em suas invenções e afetos?

Uma pausa. A tela enche-se novamente.

Dessa vez, o curta-metragem é da ordem da aflição, da organização demasiada. Um personagem aparece a preencher a totalidade da tela em sua estrutura de cômoda. Um personagem-cômoda que basta a si mesmo para satisfazer suas necessidades. O ápice da organização e do individualismo.

Começa a cena, e a sonoridade plácida e reconfortante do curta-metragem anterior é substituída pelo estrondo de um despertador que marca o início milimétrico de uma vida matematicamente distribuída. Abre-se uma gaveta e escova os dentes, abre-se outra e o café é feito, abre-se outra, e outra, e outra, e outra, e tudo é devidamente acertado para não sair do lugar. Plena métrica da perfeição. Imagens-cinema nas quais a atenção à vida é evidenciada pelos esquemas sensório-motores do personagem; uma vida dividida em gavetas que devem abrir conforme às pressões do tempo vivenciado. Seriam nossas vidas conduzidas por uma métrica perfeita? Distribuímos nossos afazeres em gavetas e deixamo-nos enquadrar por elas? 


\section{Imagem 4 -A métrica da perfeição}

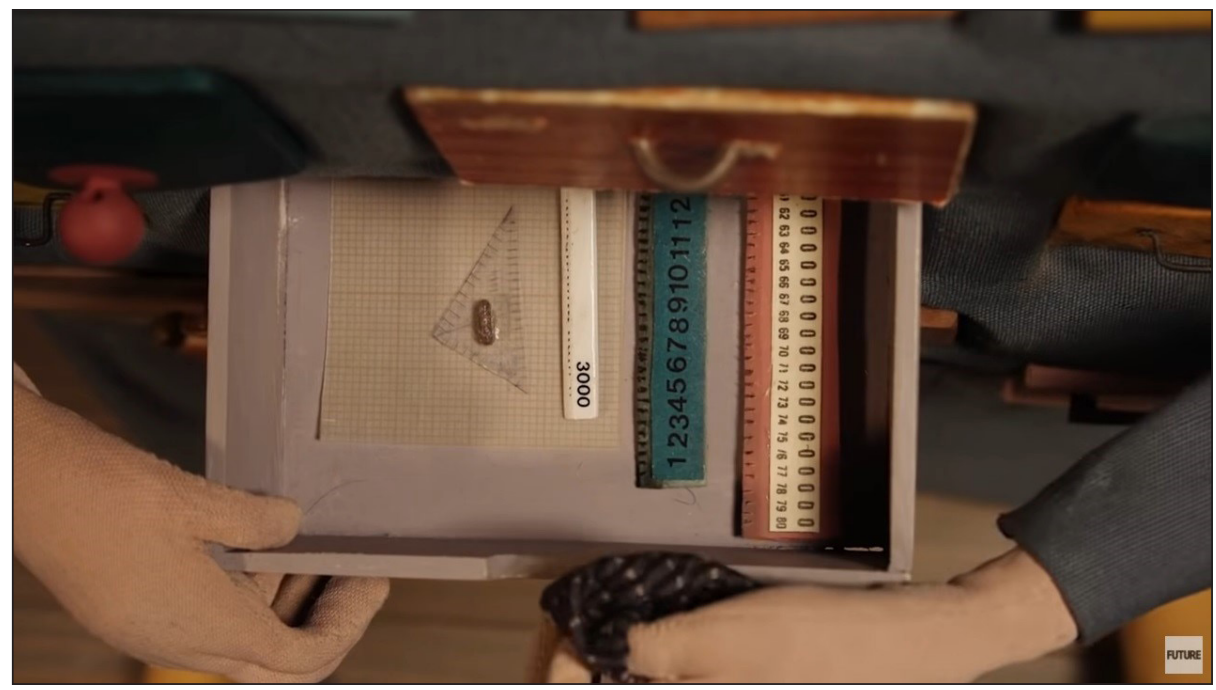

Fonte: Piirongin Piiloissa (2011).

Fora o alarme e o abrir e fechar das gavetas, nenhum outro som invade a tela, até que somos cortados por um som travesso, por uma música que esperaríamos ouvir junto a uma trupe de crianças levadas prontas para aprontar a próxima. E, acompanhando a narrativa do curta, percebemos uma coisa: somos os únicos atravessados pelo som. O corpo-cômoda continua a se organizar infinitamente, embora forçado aos movimentos de diferenciação. Vemos, assim, imagens outras, não dogmáticas, instigando perfurações nos esquemas sensório-motores.

Afinal, o que quer aquele som sem rosto, aquela música sem corpo?

Aos modos de Deleuze (2016, p. 165), precisaríamos começar a pensar nesse som como uma força que só existe nesse cenário como um todo - "[...] não é o som que remete a uma paisagem, mas é a própria música que envolve uma paisagem propriamente sonora que the é interior". Depois, de imediato, poderíamos começar a dar movimento ao som, dar cores ao som. O passo ritmado da travessura que espreita o personagem-cômoda carrega consigo uma série de cores em vias da acontecência. Será o momento pintado em cores quentes abrasadoras? Em cores frias de corpo estupefato? Nada sabemos ainda. Todavia, temos uma certeza: o som indica a presença de uma personagem que não há de deixar a vida em sua placidez atual. 
Vendo os rostos das professoras aos indícios da presença sonora, víamos sorrisos travessos se espalharem. As vias da acontecência já marcavam a presença em seus corpos. As múltiplas durações sofrem interferências que fazem variar o pensamento.

Pois então, não há surpresas com o rompimento contínuo do corpo-cômoda.

Toca o despertador uma vez mais, abre gaveta, fecha gaveta, abre... de novo, mas, dessa vez, por outra força. O som das gavetas fechando-se e abrindo já não é a única sonoplastia no curta-metragem. As próprias gavetas ganham vida enquanto um som de mistério e brincadeira se expande pela tela.

O curta ganha velocidade e intensidade. O corpo-cômoda, desacostumado à agitação, vê-se suado pelo esforço em capturar o som que lhe incomoda. E, no ato desesperado de encontrar o som impossível, segue a vida a seu próximo arrombo audível e se depara com uma brecha sonora que nem sequer sabia existir. Espia por um buraco e, de repente, não mais gavetas nem travessuras se ouvem. O espaço sonoro é invadido pelos risos de uma tarde ensolarada num parque.

\section{Imagem 5-A brecha sonora}

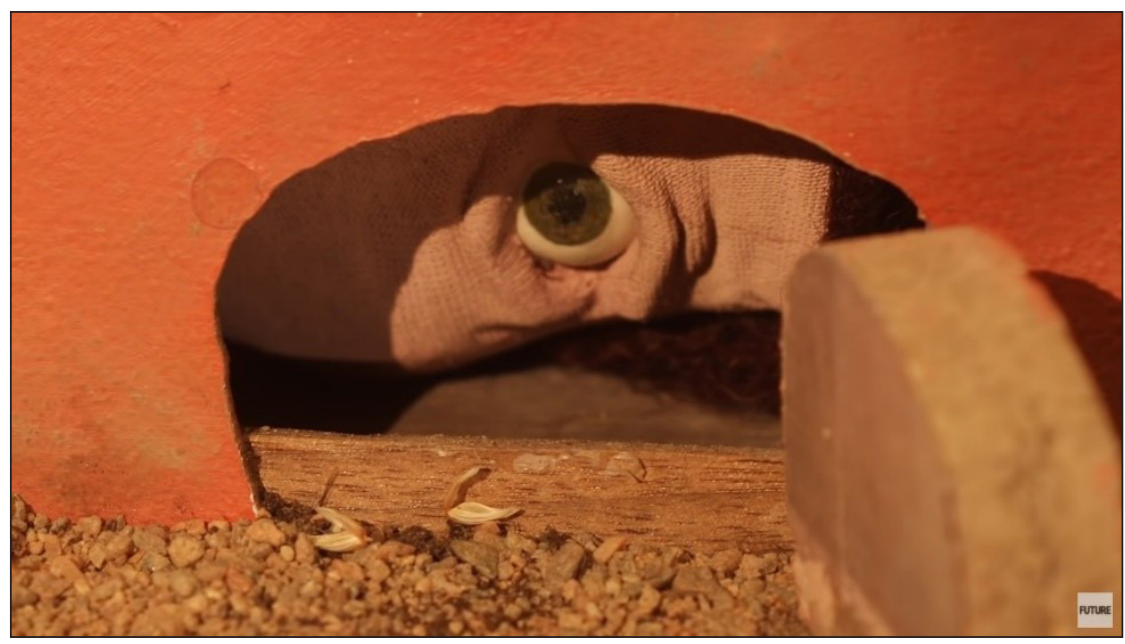

Fonte: Piirongin Piiloissa (2011).

Acho que cortou o final quando ele consegue ir para a vida e derrubar a parede...

Mas ficou até legal o corte também, porque possibilitou a gente a imaginar. Quando ele olhou aquele buraquinho, eu falei assim: "Ah, agora ele viu que 
tem algo a mais do que aquele mundinho dele, que ali tem um novo mundo que ele gostou pelo olho dele, um olho só, mas ele gostou do que ele viu..."

Eu achei muito lindo. Eu vi várias vezes e cada vez que a gente assiste é uma percepção. Agora, nesse último momento, eu pensei que quando a caixinha saiu, foi cedida a ela uma ferramenta que foi o serrote para que ela pudesse ampliar a sua abertura e foi muito interessante o barulho lá fora das crianças brincando... mas o que me chamou muita atenção é que, de repente, nós somos essas traças que aparecem possibilitando essas pequenas ferramentas, essas aberturas, mostrando que num mundo há imensas possibilidades... Assim, tem muita coisa, mas o que me chamou atenção agora foi isso.

Vida sonora, invadida pelo som de uma traquinagem que, após um movimento abrupto, irrompe em mais vida. Mais uma vez, vislumbramos, por meio das imagens-cinema, possibilidades de o apego à vida potencializar outros/novos possíveis. Gavetas fixas já não fazem sentido.

Voltemos um pouco a Deleuze para retomar as questões anteriormente apresentadas.

Perguntávamos, antes, pelas possibilidades de ultrapassar a robotização da vida e/ou, a partir do segundo curta-metragem, ultrapassar a ausência de sonoridade da vida.

Com base nas leituras que temos empreendido, tem-nos parecido que uma das formas mais potentes nesse sentido é a própria arte. Temos apostado, com base em Gilles Deleuze (2013; 2018), na arte como aquilo capaz de expandir os limites do real. Aos modos da sonoridade, ser-nos-ia, por exemplo, necessário perguntar pelos sons inaudíveis. O filósofo, fazendo uma discussão lindíssima sobre a música, diz: "Não há ouvido absoluto, o problema é ter um ouvido impossível" e, por sua vez, o trabalho da filosofia e da arte seria, então, o de "[...] tornar audíveis forças que não são audíveis em si mesmas" (DELEUZE, 2016, p. 167).

Aos modos dessa aposta, voltamos ao curta Piirongin Piiloissa (2011) justamente para ver como, ali, a sonoridade é o que mais grita com os corpos. Afinal, o que se espalha pelo som sorrateiro? O que escorre em vida, quando ouvimos os objetos serem atirados pelo espaço em direção ao chão? O que se promete quando se ouvem as risadas? O que acontece quando o som do serrote corta o silêncio da organização e do previsto?

Tudo ficava muito cronometrado, muito guardado. O que a gente poderia fazer com aquelas linhas? Com tantas criatividades, no entanto, ela só or- 
ganizava. Então, o conhecimento estava ali, mas ele não era potencializado. Pensar nessa questão do currículo prescrito mesmo, encaixotado, "agora você fecha o livro de Português porque nós vamos abrir o de Matemática", como se a vida não fosse enredada ot empo todo.

Eu fiquei pensando ali no planejamento, quando ela ia trazendo as caixinhas estava funcionando tudo tão direitinho, tão quadradinho, a caixinha fechava, a caixinha abria (risada)... De repente, não deu certo! E não dá certo mesmo. Que bom que não deu certo, porque a vida não é essa fragmentação, a vida fragmentada, e a gente, às vezes, tem muita dificuldade em alguns contextos de trabalhar. Eu falo bem assim: "eu sou uma professora e eu compraria um livro só" (risada), porque eu sou muito difícil de trabalhar com o prescritivo, então, quando ele abre a caixinha, a professora falou aí, das áreas, dos componentes curriculares, das disciplinas, enfim, "agora é Matemática, fecha o livro, menino, abre o livro". Que nó que a gente dá na cabeça dessa criança porque a vida lá fora não é isso, ela sai e ela tá lendo o mundo, tá vendo coisas, está tudo entrelaçado. E aí quando ele descobre que existem outras possibilidades e aquilo começa a se embaralhar, e dar um nó, aí vem esse mundo novo. O serrote, no meu olhar, representou isso também, essa abertura para uma nova possibilidade, digamos assim, e esses são os nossos desafios que a gente vivencia porque a gente aprende também com o colega, com a própria criança que tem nos ensinado pra caramba. Tem muita coisa, né?

Complementando a fala da colega, o que me chama atenção nesse vídeo é o fato de nós, como professores, não nos tornarmos caixas. Porque com o passar do tempo, nós vamos nos tornando caixas, você fica muito tempo dentro de uma escola e você começa a acumular... Porque eu sou aquela professora que dá trabalho ao coordenador, eu faço alguns movimentos na escola, eu trago propostas diferentes e, às vezes, o coordenador não gosta muito, né? Porque faz esse barulho. Então, quando eu vi aquela caixa se movimentando, trazendo essas possibilidades para a luz, com aquele som gostoso de crianças, eu falei: "Caramba! A gente precisa ter isso, não podemos deixar isso morrer, nós não podemos nos tornar essas caixas!".

Grosso modo: poderíamos dizer que, ao interromper o abrir-e-fechar de gavetas com o som do serrote e da travessura secreta, é o próprio acontecimento que acontece. Esses sons-acontecimentos são aberturas não de gavetas que fixam enquadramentos, mas de múltiplos mundos possíveis que fazem rachar a atenção à vida e expandem o apego à vida pela própria força da vida. Não seria isso justamente a força da imagem-tempo? 
A partir do primeiro curta-metragem, L3.o (2014), víamos o pequeno robô exprimir todo o seu modo de conhecer por meio da reprodução precisa e mortificante para que a vida fosse capturada em sua máxima perfeição. Ali, mediante a leitura deleuziana, deparávamos com o oposto do conceito de acontecimentos, isto é, deparávamos com a efetuação das forças controladoras sobre a vida. Relação conjugal do arco sensório-motor com a produção de conhecimento. Produz-se conhecimento pela morte, pela destruição das virtualidades, por um excesso de atenção à vida. Com o robô, vemos que enclausuramos a vida com base no que concebemos como real, quando não atentamos aos possíveis. Congelamos nossas possibilidades e limitamo-nos a uma realidade mecânica. Limitamo-nos à atenção à vida, enxergando apenas as formas sociais impostas. Leo nos mostra que, como disse uma das professoras, amizade assim ninguém quer. Portanto, ao buscar congelar os processos de diferenciação, apenas potencializamos individualismos e interesses vazios.

Ora, a questão no segundo curta muda radicalmente. Partimos, ali, de um movimento de vida demasiadamente organizada para vida em contínua expansão. Algo se passa - um sem-rosto, um som-vida - e acarreta uma debandada radical do próprio modo de vida do corpo-cômoda. Eis, justamente, o acontecimento (LAZZARATO, 2006), a mudança subjetiva do corpo-armário que deixa sua compartimentalização superorganizada de lado para se afetar por um som que ele pode apenas vislumbrar por um pequeno buraco.

Assim, as imagens-cinema apresentadas, de modo especial com base em Piirongin Piiloissa (2011) com seu personagem engavetado, movimentam a memória das professoras e fazem-nas atualizar enunciações acerca da vida que jorra nas escolas, dos limites que são impostos, mas que também são rasurados pela emoção criadora que expande o apego à vida. Vislumbramos as escolas como campos moventes, nas quais o tempo não é vivido passivamente por um badalar de um despertador. O apego à vida tira-nos da sedimentação das relações e, nas escolas, essa tendência abre fissuras para que processos aprendentes inventivos sejam atualizados. "Nós não podemos nos tornar essas caixas", diz uma professora. Logo, podemos transpor os enclausuramentos curriculares que são impostos nas escolas, evidenciados pelos documentos prescritivos, para operarmos por agenciamentos, não por acomodação, desobstruindo nossos poros de respiração e indo ao encontro dos risos que nos esperam nas brechas da vida. 


\section{4 “NÓS NÃO PODEMOS NOS TORNAR ESSAS CAIXAS!”}

O convite da professora marca-nos: "Não podemos nos tornar essas caixas!". Caixas-arquivos que parecem, unicamente, atentar à vida sem, contudo, apegar-se a ela. Caixas-divisórias que geometrizam todo o conhecimento e todo o modo de se relacionar com ele.

Questão curricular: Como fugir das caixas? Como não mortificar a vida para afirmar que tudo na escola é experimentação curricular? A pandemia também cobra o seu preço de nossos corpos: divisória dos espaços, distanciamento, apropriação individual de todo material... "Mas e agora? Como ensinar assim? Como ensinar sem ter tão próximo? Ou aproximar-se de forma diferente?".

As falas das professoras remetem ao processo de potencialização por meio do cinema de visão, segundo Deleuze $(1985 ;$ 2013), característico do cinema moderno, em que o movimento é dependente do tempo que instaura, pela superação do arco sensório-motor, a não subordinação das imagens a um tempo cronológico. O cinema moderno em Deleuze (2013) postula que os esquemas sensório-motores não permitiam ver o mundo, por somente reproduzirem clichês e darem respostas prontas. Entretanto, ao mesmo tempo, afirma que ele seria capaz de escapar dos clichês criando uma verdadeira imagem, pois não vivemos propriamente num mundo de imagens, mas num mundo de clichês, sendo necessário procurar e encontrar uma saída (MACHADO, 2009).

Temos, desse modo, a passagem de um cinema de ação sequencial a um cinema que cria personagens que compreendem ou conhecem o que o mundo tem de intolerável, com o objetivo de resistir - pois resistir é diferente de reagir -, com o objetivo de contribuir para a criação de novas formas de vida, ou de um novo tipo de relação do homem com o mundo, no caso, com os currículos escolares em seus processos de aprendências de professores e estudantes, unindo, dessa forma, a inteligência em seus movimentos de atenção à vida com a emoção em seu apego à vida.

Isso porque, assim que a atenção à vida "[...] se separa da emoção que a carrega, ela reprime o 'desenvolvimento orgânico' desta última para substituí-lo pela ordem lógica das suas representações” (LAPOUJADE, 2017, p. 111). Enfim, toda criação supõe a coexistência desses dois níveis, pois é o conjunto dos atos de atenção à vida em conjunção com os afetos criadores que nos ligam à vida. 
Há, deveras, uma pandemia que nos exige uma contínua atenção à vida, um permanente ajuste às normas de convívio social. Todavia, conforme lembra a professora, não podemos nos ater apenas a ela. A vida há de durar. Por isso, é preciso indagarmos pelos espaços-tempos curriculares para além e aquém de toda e qualquer pandemia, de toda e qualquer excessiva atenção à vida.

Os dois curtas-metragens a que assistimos com as professoras expõem o excessivo enquadramento da vida como foco, todavia não produzem apenas uma sequência de ações-reações. Ali onde a vida é mais maltratada, no L3.o, ficamos no abalo da imagem que não dá nenhuma continuidade, mas apenas corta. Não sabemos se é o escuro da cena do corredor que nos tira o ar ou o sentido daquele monte de dobraduras que representam a planificação-mortificante da vida.

Como nos relacionamos com os currículos nos cotidianos escolares? Permitimos que a vida emerja nele para além da geometrização das dobras de um papel? O que fazemos com os sons inaudíveis que nos invadem e exigem de nós serrotes para abrir nossas caixas-corpos?

A escrita deste textoartigo buscou debater, por meio de redes de conversações estabelecidas com professoras, os limites do exercício curricular. O que pode o currículo em relação a um aumento de nosso apego à vida? Ou seja, como o "apego à vida", em sua relação com a "atenção à vida", pode superar uma perspectiva de inteligência que distrai professores e alunos da própria vida? $\mathrm{Na}$ escola, tudo compõe o corpo social, toda relação curricular é dirigida para o social, necessita do apego aos outros como um apego a si mesmo, enfim, do "apego à vida" não em suas formas, mas àquilo que nos seres é movimento no tempo. Enfim, vimos nascer uma experimentação voltada para potencializar uma docência não dogmática, baseada na perspectiva de um tempo não somente cronológico, mas no "sem-fundo" (LAPOUJADE, 2015) da multiplicidade temporal produtora de presente e futuro que permita uma aprendizagem inventiva possibilitada por um devir-docência criativo.

Concluímos, desse modo inconcluso, afirmando o "apego à vida" como necessário para liberarmos nossas vidas e permitirmos a passagem da pulsão vital, como um exercício intensivo da sensibilidade entre as forças do corpo e do mundo, que dão acesso à potência de criação e, assim, das problematizações e criações docentes. 


\section{REFERÊNCIAS}

BERGSON, Henri. Matéria e memória: ensaio sobre a relação do corpo com o espírito. Tradução de Paulo Neves. São Paulo: Martins Fontes, 2006.

CARVALHO, Janete Magalhães. Fabulando currículos entre imagens dos sonhos de Kurosawa. In: ANDRADE, Nívea; ALVES, Nilda (Org.). Sonhos de escolas: conversas com Kurosawa. Rio de Janeiro; Petrópolis: FAPERJ/DP et Alii, 2014. p. 74-97.

CARVALHO, Janete Magalhães. O cotidiano escolar como comunidade de afetos. Petrópolis: DP et Alii; Brasília: CNPq, 2009.

CARVALHO, Janete Magalhães; ROSEIRO, Steferson Zanoni. Inventando tempos outros com Bergson e Deleuze em coletivos escolares: a potência da imagem-movimento e da imagem-tempo nas produções curriculares. Revista Sul-Americana de Filosofia e Educação, Brasília, v. 25, p. 83-96, 2015.

DELEUZE, Gilles. Nietzsche e a filosofia. Tradução de Mariana de Toledo Barbosa e Ovídio de Abreu Filho. São Paulo: n-1 Edições, 2018.

DELEUZE, Gilles. Tornar audíveis forças não-audíveis por si mesmas. In: DELEUZE, Gilles. Dois regimes de loucos: textos e entrevistas (1975-1995). Tradução de Guilherme Ivo. São Paulo: Ed. 34, 2016.

DELEUZE, Gilles. A imagem-tempo. Tradução de Eloísa de Araújo Ribeiro. São Paulo: Brasiliense, 2013.

DELEUZE, Gilles. A concepção da diferença em Bergson. In: DELEUZE, Gilles. A ilha deserta e outros textos. São Paulo: Editora lluminuras, 2004, p. 43-72.

DELEUZE, Gilles. A imagem-movimento. Tradução de Stella Senra. São Paulo: Brasiliense, 1985.

DELEUZE, Gilles; GUATTARI, Félix. Como criar para si um corpo sem órgãos. Tradução de Aurélio Guerra Neto. In: DELEUZE, Gilles; GUATTARI, Félix. Mil platôs: capitalismo e esquizofrenia. Rio de Janeiro: Editora 34, 1996. p. 9-29.

DELEUZE, Gilles; GUATTARI, Félix. Um só ou vários lobos? In: DELEUZE, Gilles; GUATTARI, Félix. Mil platôs: capitalismo e esquizofrenia 2, v. 1. Tradução: Aurélio Guerra Neto. São Paulo: Ed. 34, 1995.

FUTURE. Piirongin Piiloissa | Future Shorts. YouTube, 18 jun. 2016. Disponível em: https:// www.youtube.com/watch?v=HwUZ2kH1id0. Acesso em: 22 ago. 2021. 
ISARTDIGITAL. L3.o. YouTube, 12 set. 2014. Disponível em: https://www.youtube.com/ watch?v=dQT3wD9gweE. Acesso em: 22 ago. 2021.

LAPOUJADE, David. Potências do tempo. Tradução de Hortensia Santos Lencastre. 2. ed. São Paulo: n-1 Edições, 2017.

LAPOUJADE, David. Deleuze, os movimentos aberrantes. Tradução de Laymert Garcia dos Santos. São Paulo: n-1 Edições, 2015.

LAZZARATO, Maurizio. As revoluções do capitalismo. Tradução de Leonora Corsini. Rio de Janeiro: Civilização Brasileira, 2006.

LINS, Daniel. Bob Dylan: a liberdade que canta. São Paulo: Edições Ricochete, 2018.

LOURENÇO, Suzany Goulart. A força do riso como máquina de luta entre a atenção e o apego à vida: cartografias das aprendências em uma escola pública. Tese (Doutorado em Educação) - Universidade Federal do Espírito Santo, Vitória, ES, 2019.

MACHADO, Roberto. Deleuze, a arte e a filosofia. Rio de Janeiro: Editora Zahar, 2009.

\section{Sobre os autores:}

Steferson Roseiro: Doutorando em Educação pela Universidade Federal do Espírito Santo (UFES). Professor da Rede Municipal de Ensino de Cariacica, ES. E-mail: dinno_sauro@hotmail.com, Orcid: http://orcid.org/0000-0003-1424-2281

Suzany Lourenço: Doutora em Educação pela Universidade Federal do Espírito Santo. Professora da Universidade Vila Velha (UVV) e da Rede Municipal de Ensino de Serra, ES. E-mail: suzany.goulart@gmail.com, Orcid: http://orcid.org/0000-0002-4404-772X Janete Carvalho: Doutora em Educação pela Universidade Federal do Rio de Janeiro. Professora do Programa de Pós-Graduação em Educação da Universidade Federal do Espírito Santo (UFES). E-mail: janetemc@terra.com.br, Orcid: http://orcid.org/0000-0001-9906-2911 